The President moved a vote of thanks to the respective authors, and referred to the great interest which had been added to the study of the Carboniferous Rocks by the zoning work of Dr. Vaughan in the Avon gorge and its application to other districts by Mr. Sibly. He also congratulated Professor Reynolds on his discovery of igneous rocks of Silurian age in the Mendips. Mr. E. T. Newton also spoke, and Professor Reynolds replied.

A specimen of Nautilus from the Lower Greensand quarry at Preston Hall, near Aylesford, which had been visited by the

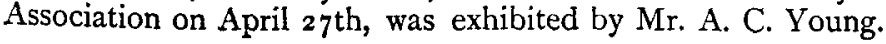

\title{
EXCURSION TO FARINGDON.
}

MAY 4 TH, 1907 .

Director: Llewellyn Treacher, F.G.S.

Excursion Secretary: GeORGE W. Young, F.G.S.

(Report by The DiReCTOR.)

THE stormy weather of the previous night prevented all but the most ardent field geologists making the early start from town which was necessary. However, about a dozen members and friends met the Director at Challow Station at I r.35, the London contingent arriving by a train specially stopped for the occasion, and the day turned out beautifully fine.

The party drove first to Stanford-in-the-Vale, where, at the western end of the village, they entered the Corallian quarry described long ago by Dr. Mantell in the "Excursions" at the end of his "Medals of Creation." The weathered face of old excavations can be seen surrounding several acres of ground on both sides of the main road to Faringdon, but the only portion worked at the present time is on the east side. The general section exposed is :-

5. Dark loamy soil, in which prehistoric implements have been found. $-\mathrm{I} \frac{1}{2} \mathrm{ft}$. 4. Coral Rag-Broken corals and echinoderms, with the interstices flled with clay $-4 \mathrm{ft}$.

3. Coralline Oolite-Hard, blue-hearted, flaggy rock with a few small pebbles of quartz, chert and lydian stone, the flagstones alternating with occasional layers of coarse rubbly oolite. $-5 \mathrm{ft}$.

2. Coarse oolitic sand-6 inches, passing down into.

I. Lower Calcareous Grit-Yellow sand, false-bedded in places. Water at bottom of quarry-about $3 \mathrm{ft}$. shown.

The relative proportions of the hard and soft layers of Bed 3 vary somewhat when traced along the face of the quarry, but the composition and thickness of the other beds, of the coral bed in 
particular, remain very constant. The coral bed appears to form the sub-soil over some extent of country hereabouts, and was formerly much used for road metal; remains of old workings being noticed in many places near the roadsides. The Kimeridge Clay comes on at the other end of Stanford village, where it is dug for brickmaking.

Although but little time was allowed for collecting, a fair number of fossils were obtained, including, from Bed 2, Exogyra nana, Ostrea (a medium-sized form), Belemnites abbreviatus (worn and covered with small oysters). From the hard crystalline matrix of Bed 3 specimens could only be extracted with difficulty, but Gervillia aviculoides, Trigonia perlata and teeth of Lepidotus maximus were noted. The Corals in Bed 4 were chiefly belonging to the genera Thecosmilia, Thamnastrea and Isastrea, in rather poor condition, associated with Cidaris florigemma (tests and spines), Pseudodiadema versipora, Lithodomus inchusus, Littorina muricata and Pecten articulatus. No division between the palæontological zones could be detected owing to the lack of the zonal Ammonites in place, but a fragment of $A$. perarmatus was found among the oolitic débris of Bed 3 , so that either this species occurs here above its proper zone, or the zone of $A$. plicatilis must be extremely thin in this district.

The drive was then continued about a mile farther along the main road to Faringdon to a large quarry near the cross-road from Hatford to Shellingford. The section is much the same as at Stanford, except that the quarry being situated higher up the dip-slope the bottom is free from water, and it can be worked to a greater depth. The lower sands are more current-bedded and, like the overlying oolite, contain a good deal of wood. Bed 3 is rather thicker than at the last quarry, and there are more of the rubbly oolitic iayers and much pisolite. Its variable nature prevents any more detailed section being given, as such would only apply to one particular spot, but the whole may be compared with that given by Messrs. Blake and Hudleston, as seen by them in the Workhouse Quarry, Faringdon. Additional fossils were Pygaster umbrella, Echinobrissus scutatus, Belemnites nitidus, Myacites, Avicula, Pecten lens and Lima laviuscula. In one part of the quarry the coral bed (4) is largely made up of stiff clay, a small piece of which, when washed, yielded many perfect specimens of Thecidium ornatum, spines of Cidaris spinosa and Asteroid ossicles. Two claws of Goniocheirus cristatus and a tooth of Pliosaurus complete the list. No Ammonites were seen in place, but the workmen had put by specimens of $A$. perarmatus, $A$. cordatus, $A$. plicatilis and $A$. varicostatus, all apparently from Bed 3 .

Proceeding towards Faringdon the road rises gently but persistently up the dip-slope of the Corallian to the foot of the hill, on the crown of which grows the group of 
pine trees known as Faringdon Clump. At the top of the first ascent, near the old brickyard, a halt was made for the purpose of observing the physical features of the district. Looking towards the south-west, immediately in front is the little valley which breaches the main escarpment north-west of Faringdon, and running through the town opens out into the Vale of White Horse, near Shellingford. The floor of this valley is here paved with Corallian rocks, and on its opposite side rises the long north-west and south-east ridge of the Sponge-gravel, capped at its southern end by an outlier of ironsands, similar to those forming the highest part of the hill under the Clump. On the eastern side of the ridge the Sponge-gravel rests directly on the Corallian, but on the west, near the village of Little Coxwell, some thickness of Kimeridge Clay comes between. The Sponge-gravel does not appear to cross the Faringdon valley, as the ironsands of the Clump rest directly on Kimeridge Clay, which was formerly worked in the brickyard close by.

A small pit near the road showed a section of the sands. They appeared to be well stratified with thin layers of clay and blocks of cherty sandstone, the harder parts of which are largely composed of small spicules of siliceous sponges, like those figured by Dr. Hinde as belonging to the genus Geodia.* A sample of the clayey material when washed yielded many pieces of shells, one small Terebratula and a fragment of the Bryozoan Petaloport Cunningtoni, (Gregory), all completely silicified. Mir. Osborne White noticed grains of glauconite, but there was no trace of calcareous matter. The age of the sands, and of the Sponge-gravel, was at one time a matter of dispute, but it is now generally allowed that they belong to the Lower Greensand, the whole of the deposits probably representing the greater part of that period. In the opinion of the Director, the geological succession of events in this neighbourhood was somewhat as follows : After a wide-spread denudation of the Kimeridge Clay down to within a few feet of its base, a narrow north-and-south channel was cut still deeper and some way into the Corallian Beds. This channel was then filled up with the Sponge-gravel, and over all was laid down a thick mass of the Ironsands. Subsequent denudation has removed the greater part of the last deposit, leaving only a few outliers on the hill-tops at the Clump, Badbury Hill, and near the village of Fernham, while the Sponge-gravel has been preserved almost intact. Although it occupies an area of not more than two miles in length by half-amile in breadth, it is doubtful if it ever had a much greater extension, except perhaps towards the north, in which direction it may have rested on the Oxford Clay, if it is correct that fossils derived from that formation have heen found in the gravel.

The party then drove through Faringdon and for some distance

* Fossil Sponge Spicules, plate 2. Munich, 1830 
along the Highworth road, to a point whence a fine view was obtained of the plain of Oxford Clay stretching away northward across the valley of the Upper Thames, with the dip-slope of the Cotswolds rising beyond. Noteworthy features of the landscape were Badbury Hill on the left, the wooded ridge of Buscot standing up in the plain to the north-west, and the picturesquely-situated town of Faringdon lying along the hillside below the Clump on the right. A disused quarry close to the road showed the Coral Rag running up to the edge of the hill, thus protecting the underlying Oxford Clay, and keeping up the steep northern face of the escarpment.

Returning towards Faringdon a brief visit was paid to $\mathrm{Mr}$. Bowler's pit in the Sponge-gravel on the north side of the Swindon Road. This is the most northerly exposure of the deposit to be seen, and it is here more than $20 \mathrm{ft}$. thick. The material is finer and softer than in any of the other pits, the larger fossils, such as sponges, are much less numerous, but there are plenty of the smaller kinds. The Bryozoan known as Radiopora pustulosa is particularly abundant.

The brake was left here and the remainder of the programme carried out on foot. Proceeding towards Little Coxwell the old "Windmill" pit, now Mr. Purbrick's, was reached, and found to be as prolific as ever. The Sponge-gravel is almost entirely made up of organic remains, the inorganic portion consisting of fine quartz sand with a few pebbles of quartz, lydian stone, chert, etc. Although the face of the quarry stands up perpendicularly for more than $30 \mathrm{ft}$. yet the texture of the deposit is fairly loose except in places where it is hardened into crystalline masses parallel to the bedding planes. The absence of finer or clayey material is remarkable. If a sample of the gravel is washed the only discolouration of the water will be from iron stains. It is this quality which gives the gravel its economic value and causes it to be in great request for footpaths and garden walks. It retains its bright colour well, and is so absorbent of water that its surface keeps dry in the wettest weather. As the extent of the workings show it is not only used in the immediate neighbourhood but also exported to long distances.

The fossils may be divided into two classes, the contemporaneous and the derived. Among the latter have usually been placed the Belemnites, but Mr. Lamplugh has questioned the correctness of this arrangement, and comparing them with the Belemnites speetonensis of the North of England has suggested that they may be of the age of the Sponge-gravel or some earlier Lower Greensand deposit. With reference to this it should be noted that the Faringdon specimens also resemble Belemnites nitidus, a species very common in the Kimeridge Clay of the neighbourhood. On the previous evening the Director had obtained seventy-six specimens of this form which had been 
found in a well dug in the Kimeridge Clay at Longcot, about two miles south of the "Windinill" pit.

Of the other fossils the most important are the sponges, the larger forms of which were known to early collectors as "petrified salt-cellars." They all belong to the group of Calcisponges, and about eighteen species have been described by Dr. Hinde and Mr. E. C. Davey. Recently the Director has discovered an example of another form, now in the Jermyn Street Museum, which Dr. Hinde thinks is an undescribed Lithonine Sponge, and that sponges of this group have not hitherto been noted from the Lower Greensand.

Greatly exceeding the sponges in numbers, in species, and possibly cven in total bulk, are the Bryozoa. These minute organisms occur both as free twig-like objects and also as encrustations on sponges, shells, pebbles, and even on the freegrowing Bryozoa, hardly any suitable surface being excmpt from their growth. Sharpe and Davey have published lists of the species, many of which they have identified with foreign forms from other horizons, but their nomenclature is sadly in need of revision. Dr. J. W. Gregory has done something towards this in his British Museum Catalogue, but, unfortunately, the poverty in Faringdon specimens of the collection at South Kensington caused several species to be omitted from that work. Mr. W. D. Lang has identified one of the common smaller forms as Siphodictyum gracile, a species recorded from the Lower Aptian of Atherfield and the Upper Aptian of Folkestone.

The fossils most sought after by collectors are probably the Echinoderms. Of these, many remains of Cidaris are found, but always as detached plates and spines. They are all usually assigned to Cidaris Faringdonensis, but there appears to be another species present, the spines of which differ from those of $C$. Faringdonensis by the absence of the long, smooth neck which characterises that form and they rather resemble those of $C$. pretiosa.

The commonest Echinoderm is the Peltastes, of which several species have been recorded, but after examining some hundreds of specimens the Director is of opinion that although in. dividuals may be found which appear to differ almost specifically from each other yet the majority are intermediate forms, and as these cannot be ignored it is not very easy to draw a hard and fast line between one so-called species and other. $\mathrm{He}$ therefore prefers to call them all varieties of Peltastes Wrightii. At the same time it should be remembered that nearly all the specimens are so much encrusted and so difficult to clean that their finer details cannot always be made out. Among those recently discovered are two which, although in general appearance much like Peltastes, yet have the apical system of a true Salenia. Dr. F. A. Bather, who has kindly examined them, Phoc. Geol, Assoc, Vul. XX, Palit 2, 1907 ] 
thinks they are nearly allied to Salenia gibba. Ancther Echinoderm, which may be noticed here, is one of which Dr. Bather says. "It is probably one of the Plgasterida allied to Pygaster or Pileus. I have not as yet found the species described."

Other fossils include the Brachiopods, which are fairly numerous and have usually been relied on for the determination of the age of the deposit. Lamellibranchs, except those of the Ostrea family, are not common, and Gasteropods are almost entirely wanting.

In the short time at their disposal the members were fortunate enough to obtain examples of most of the characteristic fossils, including a good number of teeth and bones of Saurians and Fishes.

By kind permission of Mrs. Roberts the party then took a short cut across some cornfields to a pit on the eastern slope of the ridge, in what is known as the Red-gravel. This material is of a darker colour than the Sponge-gravel proper, owing to the presence of a thin film of iron covering each of its constituent parts, and giving some of the larger fossils a curious velvety appearance. The sand is coarser and pebbles are more abundant, but except in the numerical proportion of the organic remains there does not appear to be any palæontological difference between the two deposits, the only fossil peculiar to the Red-gravel being the Echinoderm Trematopyous Davidsoni. The large Nautilus, long supposed to occur only in this pit, has been noticed by the Director at least twice in the "Windmill" pit. The Red-gravel is generally considered to overlie the Sponge-gravel, but this is open to doubt, and probably nothing short of a deep cutting joining the main excavations would definitely settle the matter. Near the top of the Red-gravel in this pit are some layers of a lighter colour and looser texture than the rest of the material, a fact which is even more noticeable in a small pit farther to the east across some fields, to which time would not allow of a visit.

Mr. Hunt, who works the Red-gravel pit, had most kindly reserved his recent finds specially for this occasion, so that the members were able to secure some fine specimens of the large Nautilus, together with various sponges and other fossils, including two internal casts of a large Pleurotomaria and one valve of a Spondylus, which Mr. R. B. Newton thinks is near to the Spondylus Brunneri of Pictet and Roux, recorded from the Aptian of Switzerland.

The heavily-laden party then returned by Sand Lane to Faringdon for tea, after which the President, in proposing a vote of thanks to the Director, remarked that they had proved it possible to make a one day's excursion to Faringdon successful, and he hoped that, although it was fifteen years since their last 
visit, it would not be so long before the Association again visited that interesting district.

The members then dispersed to their various destinations, the railway party leaving by the 6.0 train.

\section{REFERENCES.}

Geological Survey Map, Old Series, Sheets 13 and 34.

Ordnance Survey Map, New Series, Sheet 253.

Ordnance Survey Maps, 6-in. scale, Quarter-sheets, Berkshire viii, S.E., and viii, S.W., price Is. each.

1844. MANTELL, G. A.--"Medals of Creation" many references.

1850. Austen, R. A. C.- "On the Age and Position of the Fossiliferous Sands and Gravels of Faringdon," Quart. Fourn. Geol. Soc., vol. vi, p. 454 .

1852. Davidson, T.- "British Cretaceous Brachiopoda," p. 2, Palcont. Soc.

1854. SHARPE, D.- "On the Age of the Fossiliferous Sands and Gravels of Faringdon," Quart. Fourn. Geol. Soc., vol, x, p. 176

1858. RAMSAY, A. C., and others - "Geology of Parts of Wiltshire and Gloucestershire." Mem. Geol. Survey, p. 30.

I86I. Hull, E., and Whiraker, W.- "Geology of Parts of Oxfordshire and Berkshire," Mem. Geol. Survey, p. I3.

1864. MEYER, C. J. A.-" Three Daysat Faringdon," Geologist, vol. vii, p. 5. I864-82. WRIGHT, T.-"British Cretaceous Echinodermata," Palceont. Soc.

1874. DAVEY, E. C.- "The Sponge-Gravel Beds of Coxwell and Faringdon," Wantage, Pavier and Roberts.

1874. Davidson, T._-British Cretaceous Brachiopoda," p. 21, Palceont. Soc.

1876. Hudleston, W. H.- "Excursion to Faringdon." Proc Geol. Assoc., vol. iv, p. $54^{8}$ (Part 9, 8d ). See also "Record of Excursions," p. 279.

I876. BaRRoIs, C.—"Recherches sur le Terr. Crét. Sup. de l'Angleterre, etc.," p. I43, Lille.

1877. DAVEY, E. C.- "Catalogue of Fossils from the Cretaceous Beds of Berkshire." Wantage, H. N. Nichols.

1883. Hinde, G. J.- "Catalogue of the Fossil Sponges in the British Museum," 4to., Iondon.

1887. Blake, J. F., and HudLeston, W. H.-"The Corallian Rocks of England," Quart. Fourn. Geol. Soc., vol. xxxiii, p. 301 .

I 892. HINDE, G. J., and WoODWARD, H. B.- "Excursion to Faringdon," Proc. Geol. Assoc., vol. xii, p. 327 (Part 8, Is.).

I895. WOODWARD, H. B.-"Jurassic Rocks of Britain," vol, v, p. I2I. Mem. Geol. Survey.

I899. GREGory, J. W.- "Catalogue of the Cretaceous Bryozoa in the British Museum," vol. i, 8vo., London.

I899-190-. Woods, H.-" British Cretaceous Lamellibranchia," Paloont. Soc.

Ig03. LAMPLUGH, G. W.-"Belemnites of the Faringdon Sponge-Gravels," Geol. Mag., dec. 4, vol x, p. 32.

Igo(?). Davey, E. C.- "The Neocomian Sponges, etc., of Little Coxwell, near Faringdon," London, Dulau and Co. 